\title{
Product mix optimization on multi-constraint production planning-a Fuzzy Mixed Integer Linear Goal Programming (FMILGP) approach: A single case study
}

\author{
Meriastuti Ginting ${ }^{1, *}$, Martin Kirawan ${ }^{1}$ and Budi Marpaung ${ }^{1}$ \\ ${ }^{1}$ Department of Industrial Engineering, Krida Wacana Christian University, 14240 Jakarta, Indonesia
}

\begin{abstract}
Creating effective and efficient production planning becomes one of the most intriguing efforts for most of the Indonesian enterprises. This study introduces an optimization model of product mix to solve the production planning problems, by considering certain multi-constraint: limited existing resources, objectives to be achieved, and fuzzy characteristics of demand and production costs. By applying Fuzzy Mixed Integer Linear Goal Programming, this study tries to determine the optimal solutions of product mix. The study consists of several steps: capacity constraint resource analysis, formulation of the optimization models, determines the products mix and the multi-criteria objective value. The proposed product mix model is then validated by conducting a preliminary study to one enterprise. The preliminary study showed that the proposed model is able to provide an increase of multi-criteria objective value by $4.81 \%$ compared to the existing conditions.
\end{abstract}

\section{Introduction}

Basically, the goal of every enterprise is to obtain optimum profit. This goal can be achieved if the enterprise is able to market their products properly, make an effective and efficient production planning and minimize the production costs. However, in practice, the enterprise is difficult to perform those three things simultaneously. The main problems that inhibit the enterprise to achieve its goals are complexity in production planning due to the limited resources, uncertain amount of demand, and the variations in the cost of production [1].

One of the most important production planning decisions is to determine the optimal product mix on production systems. Determination of the optimal product mix is considered very important in relation to the profit earned by the enterprise [2]. By achieving an optimal product mix, an enterprise is able to increase profits and minimize production costs. Musaki revealed that by achieving optimal product mix, enterprises were able to increase net profit

\footnotetext{
Corresponding author: meriastuti.ginting@ukrida.ac.id
} 
by $1.9 \%$ on a production line [3]. The more the production output produced, the greater the profit earned by the enterprise. On the other hand, by optimizing the product mix, the production costs can be reduced by $5 \%$ to $10 \%$ [4].

Due to the limited resources, the determination of the optimal product mix in production planning by using the theory of constraints concept is very important and become a crucial issue that requires managerial attention.

\section{Literature Review}

Theory of Constraints (TOC) concept has been widely discussed to solve various problems in the various fields such as to increase net profit, to improve productivity, to reduce the production costs, to achieve service excellence, to improve the efficiency of business processes, to regulate the distribution of the logistics sector, to optimize the maintenance of law permits ownership of motor vehicles, weapons, and pets [3-7].

Linear Goal Programming (LGP) is one of the mathematical models that widely used as a basis for making decisions to analyze and create solutions to the problems that involve multiple objectives, in order to obtain optimal alternative solutions. It is a well-known method that has been applied to find the optimal solution in various fields including in production planning under TOC [3, 4]. Mix Integer Linear Goal Programming (MILGP) is LGP that just expecting certain variables that must be a non-negative integer. This model has been used to solve the multiple constrained resources product-mix problems under the TOC to find the optimal solution from the output of a production system that has some limited resources [2].

The other side, the fuzzy concept also has been widely used to solve various problems in the various fields. Fuzzy linear programming (F-LP) has been applied to calculate the maximum net profit obtained by an oil refinery industry [1], to find the minimum cost in transportation issues [8], to develop a framework for the selection of suppliers [9], to design timetable of train scheduling [10].

In this study, we propose a new Fuzzy Mixed Integer Linear Goal Programming (FMILGP) to solve the multiple constrained resources product-mix problems under the TOC. This model has never used before to solve the multiple constrained resources product-mix problems under the TOC but has been successfully used to determine an optimal solution from a given set of alternatives of design requirement in Quality Function Deployment (QFD) [10]. Different from previous studies, four conflicting goals are considered. In which the priority of the goals is determined by performing some calculations using Analytical Hierarchy Process (AHP) method after conducting an interview with the expert from a select enterprise. Besides, to determine the coefficient of variable in the constraints, S-curve membership function is applied, because it is has been tested, proven, and suitable for solving various applied problems, particularly in production planning, rather than the other membership functions, such as triangular, trapezoidal, and else [11].

\section{Methodology}

This study is an applied quantitative research. For the preliminary purpose, this study proposes a new optimization model for solving product mix problem within a tissue enterprise. This study composes several steps.

First, to determine the capacity constraint resources by comparing required capacity with available capacity. Capacity constraint resources occur when the required capacity is greater than the available capacity. 
Second, to determine the goals and the priority of the goals and all the constraints of the product mix problem. The priority of the goals is determined by performing some calculations using The Analytical Hierarchy Process (AHP) method after conducting an interview with the expert from a select enterprise. AHP is a multi-criteria decision-making method, it is a structured technique for organizing and analyzing complex decisions.

Third, the design of the product mix optimization model is constructed. The formulation of the optimization model is developed to obtain the optimal product mix output by using Fuzzy Mixed Integer Linear Goal Programming (FMILGP) [7]. In this step, the objective function and all of the constraints will be collected to create the initially proposed model. It is relatively the same as the usual Linear Goal Programming (LGP) model.

Subject to :

$$
\operatorname{Min} \mathrm{Z}=\Sigma\left(\mathrm{P}_{\mathrm{y}} \mathrm{d}_{\mathrm{i}}^{+}+\mathrm{P}_{\mathrm{s}} \mathrm{d}_{\mathrm{i}}^{-}\right)
$$

$$
\begin{gathered}
\sum g_{k j} X_{j} \leq o r \geq C_{k} \\
\Sigma\left(a_{i j} X_{j}\right)+d_{i}{ }^{-}-d_{i}{ }^{+}=b_{i} \\
X_{j} \geq 0 \text { and integer } ; d_{i}{ }^{-}, d_{i}{ }^{+} \geq 0 \\
k=1,2, \ldots, p \quad ; \quad j=1,2, \ldots, n \quad ; \quad i=1,2, \ldots, m
\end{gathered}
$$

For

Where:

$$
\begin{array}{ll}
\mathrm{P}_{\mathrm{y}} \text { and } \mathrm{P}_{\mathrm{s}} & =\text { priority factors } \\
\mathrm{di}_{\mathrm{i}}^{-} \text {and } \mathrm{di}_{\mathrm{i}}^{+} & =\text {negative and positive goal-deviation variables respectively } \\
\mathrm{X}_{\mathrm{j}} & =\text { decision variables }\left(\mathrm{X}_{1}, \ldots, \mathrm{X}_{\mathrm{n}}\right) \\
\mathrm{g}_{\mathrm{kj}} \text { and } \mathrm{a}_{\mathrm{ij}} & =\text { coefficient of the decision variables } \\
\mathrm{C}_{\mathrm{i}} & =\text { right-hand sides of the rigid constraints } \\
\mathrm{b}_{\mathrm{i}} & =\text { right-hand sides of the goals }
\end{array}
$$

Equation (1) is the LGP achievement function, a priority linear function of the unwanted goal-deviation variables; Equation (2) represents the rigid constraints; Equation (3) represents the soft goals; and Equation (4) denotes the necessary non-negativity restrictions on the goal deviation variables and, when appropriate, non-negativity restrictions on the structural variables.

The LGP model used to assist in the formulation of the proposed FMILGP model. In the formulation of the proposed FMILGP model, the constraints from the previous LGP model will turn into fuzzy constraints. In the formulation, S-curve membership function is applied to determine the coefficient of the variable in the constraints. Fuzzy coefficient calculated by using the degree of vagueness $\alpha=13.81350956$, fuzzy constants $C=0.001$ and $B=1$, and degree of membership for the coefficient $\mu_{\mathrm{cj}}=0.5$. They are based on Vasant study related to the production planning (a type of product mix optimization) [8].

Fourth, to determine the product mix using the proposed model developed in the third step. After the optimization model had been built, it will be used to calculate the product mix (using WinQSB software). All coefficients of the variable in the constraints, as well as the right-hand side constant values, are inserted into the matrix sheet on WinQSB software. They are then calculated to obtain the result.

The final step is to evaluate whether the proposed model can provide more optimal results to the product mix problem of the tissue enterprise. The comparison of multi-criteria objective value between the existing and proposed condition is provided. Greater multicriteria objective value of the proposed condition than the existing condition means that the proposed optimization model could provide a better result (more optimal product mix). 


\section{Results and Discussion}

\subsection{Determination of the Capacity Constraint Resources, the goals and all constraints}

There are four products of tissues that are going to be manufactured: facial $\left(\mathrm{X}_{1}\right)$, napkin $\left(\mathrm{X}_{2}\right)$, toilet $\left(\mathrm{X}_{3}\right)$, and towel $\left(\mathrm{X}_{4}\right)$ tissue. PD-PM11 and PD-PM5 are automatic machines in the state of bottlenecks since the required capacity is greater than the available capacity.

There are four objectives (goals) in this problem that are going to be achieved, which are (1) maximizing profit, (2) minimizing production costs, (3) meeting the market demands, (4) utilizing all of the bottleneck resources. A quick look at the stated objectives shows that those objectives conflict with each other. It can be seen that the first and the third objective prefer high values of production output, while the second and the fourth objective prefer low values of production output. Goal programming can cope with such conflicting objectives better. This is why goal programming will be used throughout the formulation of the optimization model. The priority of goals based on AHP method is: Goal $1>>$ Goal $2>>$ Goal $3>>$ Goal 4.

There are also eight constraints imposed by the enterprise such as (1) minimum target of profit achievement, (2) maximum of the total production costs, (3-6) production plan for all products, (7-8) resources capacity availability. They are all considered as fuzzy, due to their variability. It is necessary to obtain minimum deviation variable value with a certain degree of satisfaction by using interactive FMILGP.

\subsection{The Proposed Fuzzy Mixed Integer Linear Goal Programming (FMILGP) Model}

The initially proposed model is relatively the same as the usual Linear Goal Programming model, with the restriction of all decision variables $\left(\mathrm{X}=\mathrm{X}_{1}, \mathrm{X}_{2}, \mathrm{X}_{3}, \mathrm{X}_{4}\right.$, ) are integers. " $\mathrm{Z}$ " in the objective function is the value of goal-deviation variables. Different from the previous study this model considered four conflicting goal that prioritized by using Analytical Hierarchy Process (AHP) as the objective function, and also considered eight constraints as fuzzy due to their variability.

The LGP formulation of the above stated multi-resources constrained product mix problem is:

Min. $\mathrm{Z}=\mathrm{P}_{1} \mathrm{~d}_{1}{ }^{-}+\mathrm{P}_{2} \mathrm{~d}_{2}{ }^{+}+\mathrm{P}_{3}\left(\mathrm{~d}_{3}^{-}+\mathrm{d}_{4}{ }^{-}+\mathrm{d}_{5}{ }^{-}+\mathrm{d}_{6}{ }^{-}\right)+\mathrm{P}_{4}\left[\left(\mathrm{~d}_{7^{-}}+\mathrm{d}_{7}{ }^{+}\right)+\left(\mathrm{d}_{8}{ }^{-}+\mathrm{d}_{8}{ }^{+}\right)\right]$

Subject to:

$$
\begin{aligned}
& \mathrm{p}_{1} \mathrm{X}_{1}+\mathrm{p}_{2} \mathrm{X}_{2}+\mathrm{p}_{3} \mathrm{X}_{3}+\mathrm{p}_{4} \mathrm{X}_{4}+\quad \mathrm{d}_{1}{ }^{-}-\mathrm{d}_{1}^{+}=\mathrm{MP} \\
& \mathrm{c}_{1} \mathrm{X}_{1}+\mathrm{c}_{2} \mathrm{X}_{2}+\mathrm{c}_{3} \mathrm{X}_{3}+\mathrm{c}_{4} \mathrm{X}_{4}+\mathrm{d}_{2}^{-}-\mathrm{d}_{2}^{+}=\mathrm{MC}
\end{aligned}
$$

$$
\mathrm{X}_{1}+\quad \mathrm{d}_{3}{ }^{-}-\mathrm{d}_{3}{ }^{+}=\mathrm{D} 1
$$

$$
\mathrm{X}_{2} \quad \mathrm{~d}_{4}^{-}-\mathrm{d}_{4}{ }^{+}=\mathrm{D} 2
$$

$$
\mathrm{X}_{3} \quad \mathrm{~d}_{5}{ }^{-}-\mathrm{d}_{5}{ }^{+}=\mathrm{D} 3
$$

$$
\mathrm{X}_{4}+\mathrm{d}_{6}{ }^{-}-\mathrm{d}_{6}{ }^{+}=\mathrm{D} 4
$$




$$
\mathrm{t}_{11} \mathrm{X}_{1}+\mathrm{t}_{12} \mathrm{X}_{2}+\mathrm{t}_{13} \mathrm{X}_{3}+\mathrm{t}_{14} \mathrm{X}_{4}+\mathrm{d}_{7}^{-}-\mathrm{d}_{7}^{+}=\mathrm{T} 1
$$

(3b)

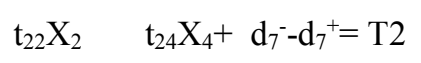

$$
\mathrm{X}_{1}, \mathrm{X}_{2}, \mathrm{X}_{3}, \mathrm{X}_{4} \quad \geq 0 \text { and integer }
$$

$\mathrm{d}_{1}^{-}, \mathrm{d}_{1}^{+}, \mathrm{d}_{2}^{-}, \mathrm{d}_{2}^{+}, \mathrm{d}_{3}^{-}, \mathrm{d}_{3}{ }^{+}, \mathrm{d}_{4}^{-}, \mathrm{d}_{4}{ }^{+}, \mathrm{d}_{5}^{-}, \mathrm{d}_{5}^{+}, \mathrm{d}_{6}^{-}, \mathrm{d}_{6}{ }^{+}, \mathrm{d}_{7}^{-}, \mathrm{d}_{7}{ }^{+}, \mathrm{d}_{8}^{-}, \mathrm{d}_{8}{ }^{+} \geq 0$

(4b)

Where:

$\mathrm{P}_{\mathrm{i}} \quad=$ the priority of four goals

$\mathrm{X}_{\mathrm{i}} \quad=$ product (i)

Di = demand (i)

$\mathrm{Ti}=$ Time/capacity available

$\mathrm{p}_{\mathrm{i}}=$ profit (i)

$\mathrm{c}_{\mathrm{i}} \quad=$ production cost (i)

$\mathrm{t}_{1 \mathrm{i}}=$ time requirement (i) in PD-PM11

t2- = time requirement (i) in PD-PM5

MP = Minimum Profit

$\mathrm{MC}=$ Maximum Cost

$\mathrm{d}_{\mathrm{i}}^{-} \quad$ = negative goal-deviation $\mathrm{i}$

$\mathrm{d}_{\mathrm{i}}^{+} \quad$ = positive goal-deviation $\mathrm{i}$

This LGP formulation used to assist the formulation of the proposed FMILGP model. In the formulation of the proposed FMILGP model, the constraints from the previous LGP model will turn into fuzzy constraints as presented in Table 1.

Table 1. Fuzzy Constraints for the Proposed FMILGP Model

\begin{tabular}{|c|l|}
\hline \multicolumn{1}{|c|}{ Description } & \multicolumn{1}{|c|}{ Fuzzy Interval } \\
\hline Profit per pack & {$[4150 ; 4300]$} \\
\hline$*$ Facial Tissue & {$[3100 ; 3200]$} \\
\hline$*$ Napkin Tissue & {$[16000 ; 16300]$} \\
\hline$*$ Toilet Tissue & {$[9700 ; 9975]$} \\
\hline$*$ Towel Tissue & {$[0.7 ; 1.1]$} \\
\hline Processing time on PD-PM5 machine/pack \\
\hline$*$ Napkin Tissue & {$[2.6 ; 3]$} \\
\hline$*$ Towel Tissue & \\
\hline Monthly Demand & {$[400000 ; 450000]$} \\
\hline Facial tissue & {$[775000 ; 800000]$} \\
\hline Napkin tissue & {$[300000 ; 350000]$} \\
\hline Toilet tissue & {$[650000 ; 675000]$} \\
\hline Towel tissue &
\end{tabular}

\begin{tabular}{|c|l|}
\hline Description & \multicolumn{1}{|c|}{ Fuzzy Interval } \\
\hline Production cost per pack \\
\hline * Facial Tissue & {$[6150 ; 6325]$} \\
\hline$*$ Napkin Tissue & {$[4625 ; 4800]$} \\
\hline$*$ Toilet Tissue & {$[23500 ; 23825]$} \\
\hline * Towel Tissue & {$[14000 ; 15000]$} \\
\hline Processing time on PD-PM11 machine/pack \\
\hline * Facial Tissue & {$[0.5 ; 1]$} \\
\hline * Napkin Tissue & {$[0.4 ; 0.8]$} \\
\hline$*$ Toilet Tissue & {$[3 ; 3.5]$} \\
\hline *Towel Tissue & {$[1 ; 1.5]$} \\
\hline Minimum profits & {$[15250 \mathrm{M} ; 16750 \mathrm{M}]$} \\
\hline Max. prod. costs & {$[22350 \mathrm{M} ; 25000 \mathrm{M}]$} \\
\hline Available capacity & {$[2484000 ; 2592000]$} \\
\hline
\end{tabular}

The mathematical model for the FMILGP problem become: 


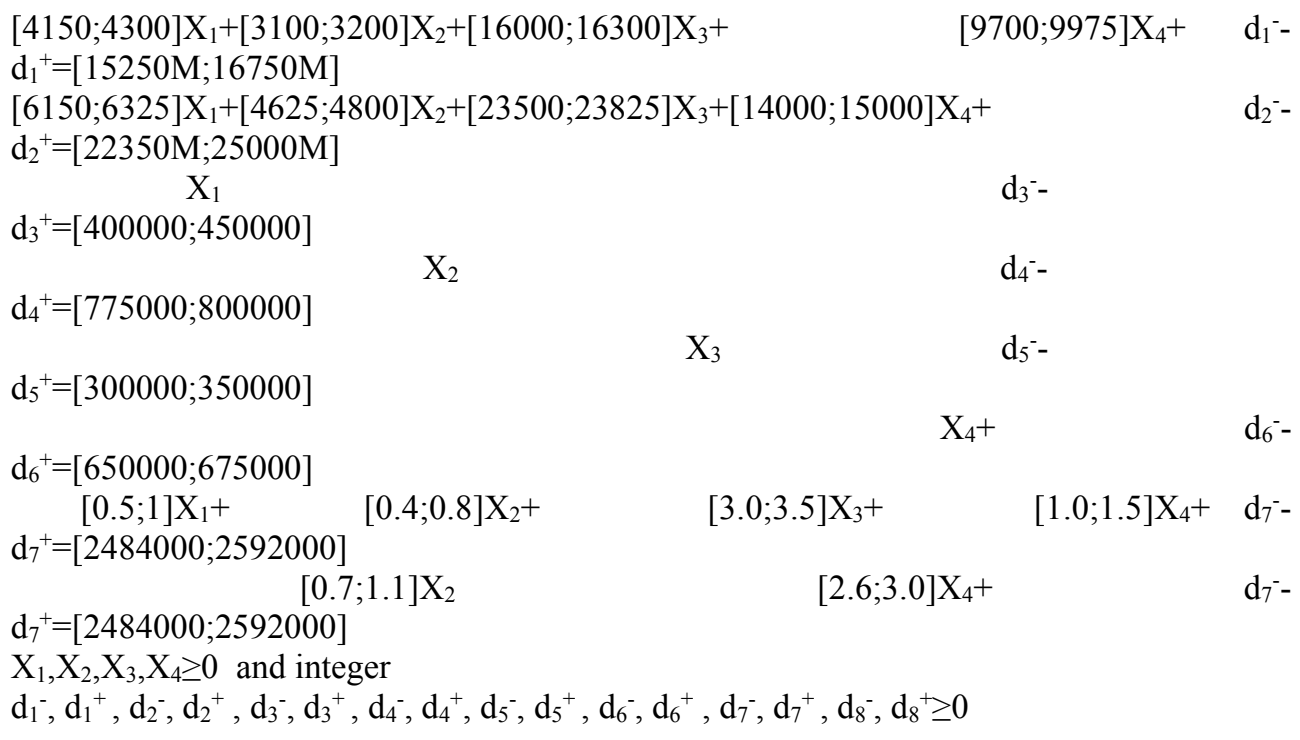

\subsection{Computation of the Product Mix using the Proposed Model}

Fuzzy coefficient of the mathematical model from the FMILGP problem above, than calculated by using S-curve membership function that given by Vasant with degree of vagueness $\alpha=13.81350956$, fuzzy constants $C=0.001$ and $B=1$, and degree of membership for the coefficient $\mu_{\mathrm{cj}}=0.5[8]$. By using WinQSB 2.0 software, the FMILGP problem has been solved the following solutions was obtained: $X_{1}=424999 ; X_{2}=791146 ; X_{3}=$ $325000 ; \mathrm{X}_{4}=662500 ; \mathrm{d}_{1}{ }^{-}=0 ; \mathrm{d}_{1}{ }^{+}=53493160 ; \mathrm{d}_{2}{ }^{-}=2005 ; \mathrm{d}_{2}{ }^{+}=0 ; \mathrm{d}_{3}{ }^{-}=1 ; \mathrm{d}_{3}{ }^{+}=0 ; \mathrm{d}_{4}{ }^{-}=0 ;$ $\mathrm{d}_{4}{ }^{+}=3646 ; 0 ; \mathrm{d}_{5}{ }^{-}=0, \mathrm{~d}_{5}{ }^{+}=0 ; \mathrm{d}_{6}{ }^{-}=0, \mathrm{~d}_{6}{ }^{+}=0 ; \mathrm{d}_{7}^{-}=0, \mathrm{~d}_{7}{ }^{+}=111686.80 ; \mathrm{d}_{8}^{-}=0, \mathrm{~d}_{8}{ }^{+}=29031.40$.

The solutions show that there are goals that can achieve and underachieve. The first goal (maximizing profit) achieved by IDR 53,493,160. The second goal (minimize production cost) also achieved by IDR 2,005. The third goal (meet the market demands) underachieved by 1 unit, and goal 4 (utilize all of the bottleneck resources) underachieved by 140,718.20 seconds. So, based on the results above, the optimal product mix are 424,999 packs for Facial Tissue, 791,146 packs for Napkin Tissue, 325,000 packs for Toilet Tissue, and 662,500 packs for Towel Tissue.

There are differences between the existing product mix and the proposed product mix. It provides different profits, total production costs, units produced and required capacity as shown in Table 2. The proposed product mix provides a larger amount of profits earned than the existing condition, it is in line with the first objective of this problem, which is maximizing profits. On the other hand, the total unit produced in the proposed condition is larger than the existing condition, whereas it is closer to the market demands. The proposed product mix also provides a higher percentage of utilization of the machine PD-PM11 and PD-PM5.

The result shows that the multi-criteria objective value of the proposed condition is larger than the multi-criteria objective value of the existing condition. This indicates that the proposed FMILGP optimization model successfully provides more optimal product mix solutions with attention to the limited existing resources, the objectives to be achieved, and the fuzzy characteristics of demand and production costs. 
Table 4. The Differences between the Existing and Proposed Condition

\begin{tabular}{|c|c|c|c|}
\hline \multirow{2}{*}{\multicolumn{2}{|c|}{ Description }} & \multicolumn{2}{|l|}{ Condition } \\
\hline & & Existing & Proposed \\
\hline \multicolumn{2}{|c|}{ Profits Earned (IDR) } & $15,267,727,308$ & $16,052,867,645$ \\
\hline \multicolumn{2}{|c|}{ Total Production Costs (IDR) } & $22,533,979,984$ & $23,692,800,255$ \\
\hline \multirow{4}{*}{ Units Produced } & Facial Tissue (pack) & 416,944 & 424,999 \\
\hline & Napkin Tissue (pack) & 757,031 & 791,146 \\
\hline & Toilet Tissue (pack) & 308,750 & 325,000 \\
\hline & Towel Tissue (pack) & 623,675 & 662,500 \\
\hline \multirow{2}{*}{$\begin{array}{l}\text { Required } \\
\text { Capacity }\end{array}$} & PD-PM11 (seconds) & $2,465,466$ & $2,590,176$ \\
\hline & PD-PM5 (seconds) & $2,417,812$ & $2,556,354$ \\
\hline
\end{tabular}

\section{Conclusions}

The proposed Fuzzy Mixed Integer Linear Goal Programming (FMILGP) optimization model through the modified S-curve membership function successfully provides optimal product mix solutions with attention to the limited existing resources, the objectives to be achieved, and the fuzzy characteristics of demand and production costs. It shows that the multi-criteria objective value in the proposed condition is larger than the multi-criteria objective value in the existing condition by $4.81 \%$.

This research has a limitation as a preliminary study that used in a particular industry. Further research should be conducted within large scope industries. Even though, the results and findings of this study had shown that FMILGP optimization model is successfully provided the optimal solutions in the production planning problem as well as the train re-scheduling problem in the previous study. It indicates that this optimization model can also be used for other cases in future research.

\section{References}

1. H.-f. Wang and K. -w Zheng, The J. of the Operational Research Society 64, 169 (2013)

2. M. Rajesh, IUP Journal of Operations Management 13, 7 ( 2014)

3. H. Musaki, M. Ginting, and B. Marpaung, JTIK UKRIDA 4, 39 (2013)

4. B. Aldeseit, Journal of Agricultural Science 6, 194 (2014)

5. M. Pophaley and R. K. Vyas, IUP Journal of Operations Management 9, 48 (2010)

6. D.S. Bernardi and Sílvio R.I. Pires, Management Research Review 33, 683 (2010)

7. W.A. Robbins, The Journal of Government Financial Management 60, 40 (2011)

8. J. Kaur and A. Kumar, J. of Opt. Theory and Applications 156, 529 (2013)

9. P. Pandey, B.J. Shah and H. Gajjar, Benchmarking : An Int. Journal 25, 1138 (2017)

10. X. Meng, L. Jia, W. Xiang, J. Xu, Kybernetes 44, 1472 (2015)

11. P. M. Vasant, Int. J. of Information Technology \& Decision Making. 4, 647 (2005) 